Acta Regionalia et Environmentalica 2

Nitra, Slovaca Universitas Agriculturae Nitriae, 2017, pp. 56-58

\title{
POTENTIAL OF MISCANTHUS × GIGANTEUS FOR HEAVY METALS REMOVING FROM INDUSTRIAL DEPOSOL
}

\author{
Gordana DRAŽIĆ* , Jelena MILOVANOVIĆ, Slobodan STEFANOVIĆ, Ivana PETRIĆ \\ Singidunum University, Belgrade, Serbia
}

\begin{abstract}
Agro-energy crop, Miscanthus $\times$ giganteus should be produced on marginal land in order to avoid land suitable for food production. Production of electricity in thermal power plants occupies large land areas by depositing tailings from surface mines, and depositing ash and slag. During the first year of Miscanthus $\times$ giganteus growing in containers, the concentration of heavy metals: As, Cd, Co, $\mathrm{Cr}, \mathrm{Cu}, \mathrm{Mn}, \mathrm{Ni}, \mathrm{Pb}, \mathrm{Zn}$ and Fe was monitored in underground and aboveground plant parts. The substrate was overburden from open pit coal mine RB Kolubara and ash from TPP Nikola Tesla B. Significant differences were found between the substrate and the investigated elements, but in all cases the accumulated heavy metals almost completely remained stable in underground organs of plant. It can be concluded that biomass of Miscanthus $\times$ giganteus could be used as energy source if it is grown on a soil moderately contaminated by heavy metals.
\end{abstract}

Keywords: agro-energy crop, heavy metals, Miscanthus $\times$ giganteus, biomass

Soil contaminated by heavy metals requires reclamation, because it cannot be used in typical agricultural production such as food or fodder. These activities contribute to restoring ecosystem services of marginal land (Nsanganwimana et al., 2014). A good way of contaminated soils management seems to be their use under energy crops cultivation (Gomes, 2012). Cultivation of perennial energy crops in the areas moderately contaminated by heavy metals, in addition to the production of biomass for energy purposes, can also help in progressive purifying of the soil and removing the contaminants (Barbosa et al., 2015). At present, studies are conducted worldwide on the possibility of using different plant species including perennial energy crops, for phytoremediation purposes (Kocoń et al., 2012, Pidlisnyuk et al., 2014). Here, they review recent literature on using miscanthus for combined biomass production and phytoremediation of contaminated and marginal lands. This review examines the production of miscanthus as a useful crop on lands with contaminants and on marginal disturbed lands where improvements in soil quality are needed.

Production of electricity in thermal power plants occupies large land areas in two ways: mining activities in open pit coal mines, which remain highly degraded by superficial disposals of overburden, and ash disposal at landfills. These surfaces require remediation and potentially contain heavy metals (HM) in elevated concentrations (Milovanović et al., 2012).

Heavy metals accumulation studies were conducted in the Miscanthus $\times$ giganteus biomass produced on the ash of the thermal power plant and tailings from lignite surface mines. The aims of studies were to determine accumulation factor and translocation of $\mathrm{As}, \mathrm{Cd}, \mathrm{Co}, \mathrm{Cr}, \mathrm{Cu}, \mathrm{Mn}, \mathrm{Ni}, \mathrm{Pb}$ and $\mathrm{Zn}$.

\section{Material and methods}

Pot experiment was performed with Miscanthus $\times$ giganteus grown on Gleysol, ash from disposal of the thermal Power Plant Nikola Tesla B, Obrenovac, and overburden from open pit coal mine Kolubara and Lazarevac in the Republic of Serbia. Miscanthus rhizomes (with a length of $10 \mathrm{~cm}$, with 3-6 nodes) were planted in the middle of April in pots containing $10 \mathrm{I}$ of substrate, fertilized with NPK $(15,15$, 15) $50 \mathrm{~kg} \mathrm{ha}^{-1}$ immediately after planting and watering once a month. The experiment was set up in triplicate. Morphological characteristics were measured at the end of the period of intensive growth in the first year, during September, when samples were taken for the analysis of the HM content.

The total content of $\mathrm{As}, \mathrm{Cd}, \mathrm{Co}, \mathrm{Cr}, \mathrm{Cu}, \mathrm{Mn}, \mathrm{Ni}, \mathrm{Pb}, \mathrm{Zn}$ in the underground (rhizomes and roots) and the above-ground (stable and lost) parts of the plant is determined by the method of atomic absorption spectrometry after extraction by wet process.

Accumulation factor is determined as the ratio of the concentration of a particular HM in the plant/concentration in the substrate. Translocation factor is defined as the ratio of $\mathrm{HM}$ concentration in the above ground part/concentration in the underground part.

The results are presented as arithmetic mean \pm standard deviation. Statistical analyses were performed applying SPSS version 13.0 (SPSS Inc., Chicago, USA). Independentsamples $t$-tests (significance set at $P<0.05$ ) were used to test differences. 


\section{Results and discussion}

Ash and overburden have favourable $\mathrm{pH}$, low content of phosphorus, nitrogen and humus (Table 1), as well as moderate content of HM (Table 2) that does not exceed the limit values except for As and $\mathrm{Co}$ in ash and $\mathrm{Co}$ and $\mathrm{Ni}$ in overburden but do not exceed the remedial values (Off. Gaz. of RS 34, No. 88/2010).

The influence of growing on ash and overburden on some morphometric characteristics of Miscanthus biomass development were shown in Table 3. Stem height, number of leaves per steam, length of green part and number of green leaves per stem and tillering amount were lower than for plants grown on soil, while leaf width and stem diameter were equal. These results lead to lower underground and aboveground biomass development. The reason for this is not only the content of HM in the substrate, but also its other characteristics (low content of nutrients and unfavorable physical characteristics). The yield of the above-ground biomass with the application of minimum agro-technical measures has been investigated in the field survey. The highest yield on Gleysol was $23.12 \mathrm{t} \mathrm{ha}^{-1}$ in 2014, on Planosol 10.16 tha $\mathrm{t}^{-1}$, and $4.77 \mathrm{tha}^{-1}$ in 2015 on Technosol (overburden). The yield of miscanthus, beside fertilization, depends on weather conditions and weeds (Dražić et al., 2017).

Contents of As, $\mathrm{Cr}$ and $\mathrm{Ni}$ in underground parts of Miscanthus are equal for ash and overburden. Concentrations of $\mathrm{As}, \mathrm{Cd}, \mathrm{Co}, \mathrm{Cr}$, Cu were significantly lower in stems than in rhizomes. Among investigated $\mathrm{HM}$ only $\mathrm{Mn}, \mathrm{Pb}$ and $\mathrm{Zn}$ accumulate in stems in concentrations equal or higher than in the substrate.

Bioaccumulation factor $>1$ was observed for $\mathrm{Cd}, \mathrm{Co}$ (in overburden), $\mathrm{Cr}, \mathrm{Cu}, \mathrm{Pb}$ and $\mathrm{Zn}$, in some cases $>3(\mathrm{Cd}, \mathrm{Cr}$ and $\mathrm{Pb}$ on ash) suggesting phytoremediation potentials of Miscanthus. In contrast, translocation factor is low in all cases.

Literature data indicate that the perennial grass miscanthus (primarily defined by results with $M$. $\times$ giganteus)

Table 1 Some agrochemical characteristics of ash and overburden

\begin{tabular}{|c|c|c|c|c|c|c|}
\hline & pH $1 \mathrm{M} \mathrm{KCl}$ & $\mathrm{pH} \mathrm{H} \mathrm{H}_{2} \mathrm{O}$ & $\mathrm{P}_{2} \mathrm{O}_{5}\left(\mathrm{mg} 100 \mathrm{~g}^{-1}\right)$ & $\mathrm{K}_{2} \mathrm{O}\left(\mathrm{mg} 100 \mathrm{~g}^{-1}\right)$ & $\mathbf{N}(\%)$ & Org C (\%) \\
\hline Overburden & 6.40 & 7,40 & 7,62 & 23,50 & 0,10 & 0,64 \\
\hline ash & 7.89 & 8.02 & 8.66 & 15.3 & 0.12 & 2.64 \\
\hline
\end{tabular}

Table 2 Total heavy metal contents in substrate $\left(\mathrm{mg} \mathrm{kg}^{-1}\right)$

\begin{tabular}{|l||c|c|c|c|c|c|c|c|c|}
\hline & As & Cd & Co & Cr & Cu & Mn & Ni & Pb & Zn \\
\hline \hline ash & 59.07 & 0.385 & 23.00 & 37.50 & 23.75 & 950.00 & 28.64 & 3.64 & 20.10 \\
\hline overburden & 4.59 & 0.71 & 16.50 & 58.75 & 19.32 & 565.5 & 78.65 & 15.14 & 48.70 \\
\hline
\end{tabular}

Table 3 Morphometric characteristics of miscanthus. S- soil, A-ash, O- overburden

\begin{tabular}{|l||c|c|c|c|c|c|c|c|c|c|}
\hline & $\begin{array}{c}\text { Stem height } \\
(\mathbf{c m})\end{array}$ & Leaf/stem & $\begin{array}{c}\text { Leaf length } \\
(\mathbf{c m})\end{array}$ & $\begin{array}{c}\text { Leaf } \\
\text { width }\end{array}$ & $\begin{array}{c}\text { Stem diameter } \\
(\mathbf{c m})\end{array}$ & $\begin{array}{c}\text { Green } \\
\text { leaf No. }\end{array}$ & $\begin{array}{c}\text { Dry leaf } \\
\text { No. }\end{array}$ & $\begin{array}{c}\text { Tillering } \\
\text { amount }\end{array}$ & $\begin{array}{c}\text { DMU } \\
(\mathbf{g})\end{array}$ & $\begin{array}{c}\text { DMA } \\
(\mathbf{g})\end{array}$ \\
\hline \hline S & 73.67 & 12.33 & 49.67 & $0.90 b$ & $0.73 c$ & 11.00 & 1.33 & 8.00 & 36.54 & 146 \\
\hline $\mathbf{A}$ & 87.12 & $10.33 a$ & 34.67 & $0.96 b$ & $0.71 c$ & $8.33 d$ & 1.67 & 3.78 & 19.36 & 68.66 \\
\hline $\mathbf{O}$ & 54.44 & $10.33 a$ & 22.86 & $0.95 b$ & $0.65 c$ & $8 d$ & 2 & 5.24 & 24.7 & 82.46 \\
\hline
\end{tabular}

Table 4 Heavy metal contents in belowground and aboveground biomass $\left(\mathrm{mg} \mathrm{kg}^{-1}\right)$

\begin{tabular}{|l||c|c|c|c|c|c|c|c|c|}
\hline & As & Cd & Co & Cr & Cu & Mn & Ni & Pb & Zn \\
\hline \hline u A & $5.6 \pm 1.21 a$ & $2.2 \pm 0.42$ & $15.7 \pm 2.24$ & $201.9 \pm 46 d$ & $36.3 \pm 8.33$ & $280.3 \pm 34$ & $20.4 \pm 3.67 g$ & $11.4 \pm 2.18 i$ & $36.7 \pm 4.22 j$ \\
\hline u O & $4.6 \pm 0.86 a$ & $3.1 \pm 0.64$ & $33.1 \pm 6.44$ & $216.9 \pm 24 d$ & $20.1 \pm 4.29$ & $514.7 \pm 48 f$ & $16.4 \pm 5.17 g$ & $16.4 \pm 1.12$ & $56.5 \pm 6.62$ \\
\hline a A & $0.6 \pm 0.08 b$ & $0.2 \pm 0.04 c$ & $4.1 \pm 0.67$ & $22.7 \pm 3.18 e$ & $4.8 \pm 0.98$ & $74.6 \pm 13$ & $10.2 \pm 1.16 h$ & $6.7 \pm 0.97$ & $20.11 \pm 3.18$ \\
\hline aO & $0.8 \pm 0.08 b$ & $0.2 \pm 0.06 c$ & $2.8 \pm 0.16$ & $34.6 \pm 6.15 e$ & $2.5 \pm 0.24$ & $502 \pm 48 f$ & $12.5 \pm 2.36 h$ & $10.8 \pm 2.11 i$ & $41.2 \pm 7.34 j$ \\
\hline
\end{tabular}
average \pm SD. A - ash, $\mathrm{O}$ - overburden, $\mathrm{u}$ - underground parts, a - aboveground parts

Table 5 Bioaccumulation factor (BAF) and translocation factor (TF) of miscanthus grown on ash (A) and overburden (O)

\begin{tabular}{|l||c|c|c|c|c|c|c|c|c|}
\hline & As & Cd & Co & $\mathbf{C r}$ & $\mathbf{C u}$ & $\mathbf{M n}$ & $\mathbf{N i}$ & $\mathbf{P b}$ & $\mathbf{Z n}$ \\
\hline \hline BAF A & 0.095 & $\mathbf{5 . 7 1 4}$ & 0.682 & $\mathbf{5 . 3 8 4}$ & 1.528 & 0.295 & 0.712 & $\mathbf{3 . 1 3 1}$ & 1.871 \\
\hline BAF O & 1.002 & $\mathbf{4 . 3 6 6}$ & 2.006 & $\mathbf{3 . 6 9 1}$ & 1.040 & 0.910 & 0.139 & 1.083 & 1.160 \\
\hline TF A & 0.107 & 0.090 & 0.261 & 0.112 & 0.132 & 0.145 & 0.5 & 0.587 & 0.548 \\
\hline TF O & 0.174 & 0.065 & 0.085 & 0.160 & 0.124 & 0.975 & 0.762 & 0.659 & 0.729 \\
\hline
\end{tabular}


has a good potential for growing on contaminated and also marginal sites which are not polluted to a high concentration (Pidlisnyuk et al., 2014; Živanović et al., 2014). Some research reports metal uptake by different plant parts, but concentrations of the contaminants within plants differ with location and depend on the nature of contaminant substances, soil conditions, time of exposure and level of growth. The level of contaminant substances taken up by aerial biomass growth is small and biomass can be used for energy production. In some cases, reported biomass growth was higher in the presence of contamination (Pidlisnyuk et al., 2014). Thus, for example, the French National Institute of Agrarian Research (INRA) carried out trials with $M . \times$ giganteus and confirmed that it tolerates high levels of heavy metals in the soil, while only accumulating low levels of cadmium in its leaves (Cadoux et al., 2008).

The growth and metal uptake by miscanthus from soils and mine waste polluted with $\mathrm{Cu}, \mathrm{Zn}$, and As were studied over a two year period in West Cornwall, U.K. The metal content in aboveground biomass was just slightly lower when miscanthus was grown on unpolluted soil and compared with data from the polluted one. Therefore, miscanthus grown on mine waste did not show greatly enhanced metal uptake (Visser et al., 2001).

Higher heavy metal concentrations in the soil negatively affected plant growth and productivity. Miscanthus was able to accumulate and remove heavy metals $(\mathrm{Cd}, \mathrm{Cr}, \mathrm{Cu}, \mathrm{Ni}, \mathrm{Pb}$ and $\mathrm{Zn}$ ) from the soil into the belowground hypogeal part of the plant, but there was no significant accumulation of heavy metals in aerial parts (Fernando et al., 2010). Miscanthus sp. Goedae-Uksae 1, a hybrid, perennial, bioenergy crop developed in South Korea, effectively absorbed $\mathrm{As}, \mathrm{Cu}, \mathrm{Pb}, \mathrm{Ni}, \mathrm{Cd}$, and $\mathrm{Zn}$ from soil and removal rate depends to heavy metal (Bang et al., 2015).

\section{Conclusions}

Miscanthus $\times$ giganteus, grown on ash from disposal of thermal Power Plant and overburden from open pit coal mine produce lower biomass during $1^{\text {st }}$ vegetative period than as grown on soil type Gleysol. Among investigated heavy metals, only $\mathrm{Cd}, \mathrm{Cr}$ and $\mathrm{Pb}$ were accumulated in underground parts in concentrations higher than in substrate but not transported into stems and leaves. The results indicate that Miscanthus possesses a certain potential for phytoremediation for some of the tested heavy metals, but HM content in overhead biomass is low so it can be used as biofuel. Further research is needed in order to enable biomass yield which is economically viable by applying intensive agro-technical measures.

\section{Acknowledgements}

This study was supported by the Ministry of Education, Science and Technological Development of the Republic of Serbia through the project TR 31078.

\section{References}

BANG, J. - KAMALA-KANNAN, S. - LEE, K.J. - CHO, M. - KIM, C-H. KIM, Y-J. - BAE, J-H. - KIM, K-H. - MYUNG, H. - OH, B-T. 2015. Phytoremediation of Heavy Metals in Contaminated Water and Soil Using Miscanthus sp. Goedae-Uksae 1. In International Journal of Phytoremediation, vol. 17, no. 6, pp. 515-520.

BARBOSA, B. - BOLÉO, S. - SIDELLA, S. - COSTA, J. - DUARTE, M. P. - MENDES, B. - COSENTINO, S. - FERNANDO, A. L. 2015. Phytoremediation of Heavy Metal-Contaminated Soils Using the Perennial Energy Crops Miscanthus spp. and Arundo donax L. In Bio Energy Research, vol. 8, no. 4, pp. 1500-1511.

CADOUX, S. - VANDERDRIESSCHE, V. - MACHET, J.M. - MARY, B. - BEAKDOUIN, N. - LEMAIRE, G. - GOSSE, G. 2008. Potential yield and main limiting factors of Miscanthus giganteus in France, identification of the needs for further research. In $16^{\text {th }}$ European Biomass Conference and Exhibition, Valencia, Spain.

DRAZIC, G. - MILOVANOVIC, J. - IKANOVIC, J. - PETRIC, I. 2017. Influence of fertilization on Miscanthus $\times$ giganteus (Greef et Deu) yield and biomass traits in three experiments in Serbia. In Plant Soil Environ., vol. 63, pp. 189-193.

FERNANDO, A.L. - DUANE, M.P. - ALMEIDA, J. - BOLEO, S. - MENDES, B. 2010. Environmental impact assessment of energy crops cultivation in Europe. In Biofuels Bioproducls and Biorefining, vol. 4, pp. 594-604.

GOMES, H. 2012. Phytoremediation for bioenergy: challenges and opportunities. In Environmental Technology Reviews, vol. 1, pp. 59-66.

KOCOŃ, A. - MATYKA, M. 2012. Phytoextractive potential of Miscanthus giganteus and Sida hermaphrodita growing under moderate pollution of soil with $\mathrm{Zn}$ and $\mathrm{Pb}$. In Journal of Food, Agriculture \& Environment, vol. 10, no. 2, pp. 1253-1256.

MILOVANOVIĆ, J. - DRAŽIĆ, G. - IKANOVIĆ, J. - JUREKOVA, Z. RAJKOVIĆ, S. 2012. Sustainable production of biomass through Miscanthus giganteus plantantion development. Annals of Faculty Engineering Hunedoara. In International Journal of Engineering, vol. 10, pp. 79-82.

NSANGANWIMANA, F. - PORRUT, B. - MENSH, M. - DOUAY, F. 2014. Suitability of Miscanthus species for managing inorganic and organic contaminated land and restoring ecosystem services. A review. In Journal of Environmental Management, vol. 134, pp. 123-134.

PIDLISNYUK, V. - ERICKSON, L. - KHARCHENKO, S. - STEFANOVSKA, T. 2014. Sustainable Land Management: Growing Miscanthus in Soils Contaminated with Heavy Metals. In Journal of Environmental Protection, no. 5, pp. 723-730.

PIDLISNYUK, V. - STEFANOVSKA, T. - LEWIS, E.E. - ERICKSON, L.E. - DAVIS, L.C. 2014. Miscanthus as a Productive Biofuel Crop for Phytoremediation. In Critical Reviews in Plant Sciences, vol. 33, no. 1, pp. 1-19.

REGULATION on a program of systematic monitoring of soil quality, indicators for assessing the risk of soil degradation and methodology for development of remediation programs. 2010. In Official Gazette of RS 34, no. 88, in Serbian.

VISSER, P. - PIGNATELLI, V. - JORGENSEN, U. - SANTOS OLIVEIRA, J. E. 2001. Utilisation of miscanthus. In Miscantlrusfor Energy and Fibre, p. 150. Jones, M. B. - Walsh, M., Eds. London : James and James.

ŽIVANOVIĆ, L.J. - IKANOVIĆ, J. - POPOVIĆ, V. - SIMIĆ, D. - KOLARIĆ, L.J. - BOJOVIĆ, R. - STEVANOVIĆ, P. 2014. Effect of planting density and supplemental nitrogen nutrition on the productivity of miscanthus. In Romanian Agricultural Research, no. 31, pp. 291-298. 